\title{
Quantitation Range
}

National Cancer Institute

\section{Source}

National Cancer Institute. Quantitation Range. NCI Thesaurus. Code C125010.

A set of values that demarcate the detection limits for a specific assay. 